\title{
Detection of Methicillin Resistance and Various Virulence Factors in Staphylococcus aureus Strains Isolated from Nasal Carriers
}

\author{
Hatice Türk Dağı, Duygu Fındık, Gamze Demirel, Uğur Arslan
}

Department of Microbiology, Selçuk University Faculty of Medicine, Konya, Turkey

Background: Staphylococus aureus can be found as a commensal on skin and nasal flora or it may cause local and invasive infections. $S$. aureus has a large number of virulence factors.

Aims: To investigate the methicillin resistance and frequency of various virulence factors in $S$. aureus nasal isolates.

Study Design: Descriptive study.

Methods: Nasal samples collected from university students were cultured in media. S. aureus was identified by conventional methods and the Staphyloslide latex test (Becton Dickinson, Sparks, USA). Antibiotic susceptibility tests were conducted, and the methicillin resistance was determined. The $m e c A, n u c, p v l$ and staphylococcal toxin genes were examined by polymerase chain reaction (PCR).

Results: S. aureus was isolated in 104 of $600(17.3 \%)$ nasal samples. In total, $101(97.1 \%) S$. aureus isolates were methicillin-sensitive and the remaining $3(2.9 \%)$ were methicillin-resistant. Furthermore, all but five isolates carried at least one staphylococcal enterotoxin gene, with seg being predominant. The tst and eta genes were determined in $29(27.9 \%)$, and $3(2.9 \%)$ isolates, respectively. None of the $S$. aureus isolates harbored see, etb, and $p v l$ genes.

Conclusion: A moderate rate of $S$. aureus carriage and low frequency of MRSA were detected in healthy students. $S$. aureus isolates had a high prevalence of staphylococcal enterotoxin genes and the tst gene. In this study, a large number of virulence factors were examined in $S$. aureus nasal isolates, and the data obtained from this study can be used for monitoring the prevalence of virulence genes in $S$. aureus strains isolated from nasal carriers.

Keywords: Methicillin resistance, Staphylococcus aureus, virulence factors
Staphylococcus aureus can be found as a commensal on the skin and nasal flora, and may cause local, severe, and invasive infections, such as bacteremia or pneumonia (1). The anterior nostrils represent the most common area for colonization of staphylococci; in fact, longitudinal studies have shown that $\sim 50 \%$ of individuals are $S$. aureus nasal carriers $(2,3)$. Curiously, nasal colonization has been identified as a major risk factor for the development of community-acquired and nosocomial $S$. aureus infections $(4,5)$.

The capacity of $S$. aureus to acquire antibiotic resistance genes is important. Methicillin-resistant $S$. aureus (MRSA) isolates have been subsequently reported in hospital and community settings worldwide. The increasing prevalence of MRSA in the hospital acquired (HA-MRSA) and the community acquired (CA-MRSA) is threatening. By definition, all MRSA (carrying $m e c A$ gene) species are resistant to betalactam antibiotics. In addition, MRSA isolates can obtain other resistance determinants. Nevertheless, nowadays, $S$. aureus colonizer strains are mostly methicillin-susceptible ones (MSSA) (3). Although some studies including healthy people have shown that the prevalence of $S$. aureus and the

A part of this study was presented as a poster at the $5^{\text {th }}$ Eurasia Congress of Infectious Diseases, 15-18 May 2013, Tirana, Albania.

Address for Correspondence: Dr. Hatice Türk Dağı, Department of Microbiology, Selçuk University Faculty of Medicine, Konya, Turkey Phone: +90 5052533638 e-mail: haticeturkdagi@yahoo.com

Received: 08.11.2013 Accepted: 05.12.2014 • DOI: 10.5152/balkanmedj.2015.150186

Available at www.balkanmedicaljournal.org 
detection of MRSA is increasing (6), in many other studies, the frequency of MRSA nasal healthy carriers is very low (7-9).

S. aureus has numerous cell-associated and secreted virulence factors that promote cellular adhesion, invasion, bacterial reproduction, and a deficiency of immune responses. Some of the virulence factors include Panton-Valentine leukocidin (PVL), toxic shock syndrome toxin 1 (TSST-1), hemolysins, exfoliative toxins (ETs), and staphylococcal enterotoxins (SEs) (10). PVL is a toxin that is usually related to complicated skin and soft tissue infections, diffuse cellulitis, necrotizing pneumonia, and osteomyelitis (11). Several toxins such as TSST-1 and SEs belong to the superantigen (SAg) family. More than 20 SAgs have been identified in $S$. aureus strains, and a minimum of $80 \%$ of clinical strains harbor at least one. SEs cause staphylococcal food poisoning, whereas TSST-1 and ETs are responsible for toxic shock syndrome (TSS) and staphylococcal scalded-skin syndrome (SSSS), respectively (12).

This study aims to investigate the methicillin resistance and rates of the TSST gene (tst), Panton-Valentine leukocidin gene $(p v l)$, exfoliative toxin genes (eta and $e t b$ ), and enterotoxin genes (sea, seb, sec, sed, see, seg, seh, sei, and sej) in S. aureus nasal isolates from healthy students in our university.

\section{MATERIALS AND METHODS}

\section{Specimen collection and bacteriological methods}

University students without any disease excluding medical school and health science students were included in the study. The students were informed about the procedure and verbal informed consents were obtained. The samples were taken from both nostrils of students using a swab. The swabs were inoculated in a tryptic soy broth and incubated at $37^{\circ} \mathrm{C}$ for 18 24 hours. Then, $10 \mu \mathrm{L}$ of broth was inoculated onto Columbia agar added 5\% sheep blood and mannitol salt agar (Becton Dickinson, Sparks, USA) using a sterile pipette. The media were incubated at $37^{\circ} \mathrm{C}$ for $18-24$ hours. All colonies similar to $S$. aureus were identified by conventional methods (Gram staining, catalase test) and Staphyloslide latex test (Becton Dickinson, Sparks, USA). Only one of the strains isolated from both agars was included in this study.

\section{Susceptibility tests}

Antibiotic susceptibility tests were conducted, and methicillin resistance was detected by the Kirby-Bauer disk diffusion method as recommended by the Clinical and Laboratory Standards Institute (CLSI). The D-test was carried out to detect the inducible clindamycin resistance (13). The following antibiot- ics were tested: penicillin (10 U), oxacillin $(1 \mu \mathrm{g})$, cefoxitin $(30 \mu \mathrm{g})$, erythromycin $(15 \mu \mathrm{g})$, clindamycin $(2 \mu \mathrm{g})$, gentamicin $(10 \mu \mathrm{g})$, tetracycline $(30 \mu \mathrm{g})$, ciprofloxacin $(5 \mu \mathrm{g})$, moxifloxacin $(5 \mu \mathrm{g})$, trimethoprim-sulfamethoxazole (1.25-23.75 $\mu \mathrm{g})$, linezolid $(30 \mu \mathrm{g})$, and mupirocin $(200 \mu \mathrm{g})$. The vancomycin susceptibility was investigated by an E-test strip (AB Biodisk, Solna, Sweden). S. aureus ATCC 25923 was used as a quality control strain.

\section{Molecular methods}

DNA extraction was performed with a commercial DNA isolation kit (Qiagen, Valencia, CA, USA) according to the manufacturer's recommendations. The presence of mecA (staphylococci methicillin resistance gene), nuc ( $S$. aureus thermonuclease gene used to confirm $S$. aureus), and $p v l$ was examined by modification using multiplex polymerase chain reaction (PCR) with specific primers (14-16). The PCR reaction mix $(50 \mu \mathrm{L})$ included $1 \mu \mathrm{L}$ of DNA, $5 \mu \mathrm{L}$ of $10 \mathrm{X}$ PCR buffer, $25 \mathrm{mM} \mathrm{MgCl}, 10 \mu \mathrm{M}$ dNTPs, $1 \mu \mathrm{L}$ of each primer (50 $\mathrm{pmol} / \mathrm{mL}$ ) and $5 \mathrm{U}$ Taq DNA polymerase. For multiplex PCR, the amplification was performed under the following conditions: $94^{\circ} \mathrm{C}$ for $10 \mathrm{~min}$, followed by 35 cycles of $94^{\circ} \mathrm{C}$ for 90 $\mathrm{s}, 49^{\circ} \mathrm{C}$ for $90 \mathrm{~s}$, and $72^{\circ} \mathrm{C}$ for $90 \mathrm{~s}$, with a final elongation of $72^{\circ} \mathrm{C}$ for $10 \mathrm{~min}$. The staphylococcal toxin genes were investigated by PCR as previously described $(17,18)$. The amplification was carried out in the LightCycler 2.0 thermocycler (Roche Applied Science, Germany). All PCR amplification products were separated on $2 \%$ agarose gel and visualized by staining with ethidium bromide using a UV light transilluminator.

The S. aureus strains ATCC 49775 (mecA negative, pvl positive) and ATCC 25923 (mecA negative, pvl positive, sea positive), and N315 (mecA positive, tst positive) were used as control strains for PCR.

\section{RESULTS}

S. aureus was isolated in 104 of the $600(17.3 \%)$ nasal samples assessed. All isolates were found to be nuc-positive. Of these, 101 isolates (97.1\%) were MSSA, and the remaining 3 isolates $(2.9 \%)$ were MRSA according to both PCR and antibiotic susceptibility tests results. The rate of MRSA carriage was $0.5 \%$. Except for five of the isolates, all others $(95.2 \%)$ were positive for at least one staphylococcal enterotoxin gene. The seg gene was detected in $93(89.4 \%)$ isolates, followed by sei in $68(65.4 \%)$, sec in $55(52.9 \%)$, seh in 37 (35.6\%), sej in $23(22.1 \%)$, sea in 14 (13.5\%), seb in $9(8.7 \%)$ and sed in 5 (4.8\%). The tst and eta genes were determined in $29(27.9 \%)$ and $3(2.9 \%)$ isolates, respectively. None of the $S$. aureus iso- 
TABLE 1. The enterotoxin genes and combinations detected in the 104 S. aureus strains

\begin{tabular}{|c|c|c|}
\hline \multirow[b]{2}{*}{ Toxin gene } & \multicolumn{2}{|c|}{ Positive strains } \\
\hline & Number & $\%$ \\
\hline sec, seg, sei & 15 & 14.4 \\
\hline seg, sei & 15 & 14.4 \\
\hline seg, seh, sei & 7 & 6.7 \\
\hline seb, sec, seg, sei & 6 & 5.8 \\
\hline$s e c, s e g, s e i, s e j$ & 6 & 5.8 \\
\hline sec, seg, seh, sei & 5 & 4.8 \\
\hline seg, seh & 5 & 4.8 \\
\hline sec, seg & 4 & 3.8 \\
\hline sec, seg, seh, sei, sej & 4 & 3.8 \\
\hline seg & 3 & 2.9 \\
\hline sea, sec, seg, she, sei & 2 & 1.9 \\
\hline sea, sec, seg, sei & 2 & 1.9 \\
\hline sea, seg, seh, sei & 2 & 1.9 \\
\hline sea, seg, sei & 2 & 1.9 \\
\hline seb, seg, sei & 2 & 1.9 \\
\hline sec, seg, seh & 2 & 1.9 \\
\hline seg, sei, sej & 2 & 1.9 \\
\hline $\mathrm{sec}$ & 2 & 1.9 \\
\hline sea, sec, seg, sei, sej & 1 & 0.9 \\
\hline sea, sec, seg, sej & 1 & 0.9 \\
\hline sea, sed, seg, seh, sej & 1 & 0.9 \\
\hline sea, sed, seg, sej & 1 & 0.9 \\
\hline sea, seg, seh & 1 & 0.9 \\
\hline seb, sec, seg, seh, sei & 1 & 0.9 \\
\hline sec, sed, seg, seh, sej & 1 & 0.9 \\
\hline sec, sed, seg, sei, sej & 1 & 0.9 \\
\hline sec, sej & 1 & 0.9 \\
\hline seg, seh, sej & 1 & 0.9 \\
\hline seg, sej & 1 & 0.9 \\
\hline sea & 1 & 0.9 \\
\hline sej & 1 & 0.9 \\
\hline
\end{tabular}

lates harbored see, etb, and $p v l$ genes. In this study, the most common combination was determined to be seg plus sei and seg plus sec in $65.4 \%$ and $49 \%$ of all isolates, respectively. Only 7 isolates encoded a single gene (Table 1).

All $S$. aureus strains were susceptible to vancomycin, trimethoprim/sulfamethoxazole, and linezolid. The susceptibilities of S. aureus strains for other antibiotics were $98 \%$ for gentamicin, ciprofloxacin, and moxifloxacin, $96 \%$ for tetracycline and mupirocin, $88 \%$ for erythromycin, and $20 \%$ for penicillin. The prevalence of inducible clindamycin resistance was $3 \%$.

\section{DISCUSSION}

S. aureus is a major human pathogen with a high virulence that causes both hospital-acquired and community-acquired staphylococcal infections. S. aureus causes skin and soft tissue infections of varying severity, from uncomplicated abscesses to life-threatening infections such as bacteremia and sepsis. $S$. aureus nasal carriage has been considered as a risk factor for the occurrence of human infections (19). In some studies, the $S$. aureus nasal carriage was detected at a frequency as high as $30 \%(3,20)$. In a study from Turkey, the carriage rate of S. aureus in Turkish elementary school children was $24.7 \%$ (21). The rate of these bacteria differs according to the population surveyed. We investigated the carriage of $S$. aureus in university students, representing young adults. Medical school and health science students were excluded because they are in contact with patients. A moderate rate of $S$. aureus nasal carriage $(17.3 \%)$ has been detected in healthy university students.

The treatment of MRSA infections is becoming increasingly difficult because MRSA strains are resistant to beta-lactam antibiotics, and can acquire other resistance determinants. Especially in the community, the frequency of infections caused by MRSA has increased in the last decade (22). It is believed that the prevalence of MRSA carriage increases in a healthy community and, therefore, the surveillance of MSSA and MRSA in the nasal carriage has been investigated in healthy individuals. The rates determined in other studies that analyzed healthy adult and children were usually less than $1 \%(7,21,23)$. In accordance with previous studies, the prevalence of MRSA nasal carriers is very low $(0.5 \%)$ in our study.

The capacity of $S$. aureus antibiotic resistance is also important. In this study, all strains were susceptible to trimethoprimsulfamethoxazole, vancomycin, and linezolid. The susceptibilities of $S$. aureus strains for other antibiotics were $98 \%$ for gentamicin, ciprofloxacin and levofloxacin, $96 \%$ for tetracycline and mupirocin, $88 \%$ for erythromycin, and $20 \%$ for penicillin. The prevalence of inducible clindamycin resistance was $3 \%$. The higher resistance to erythromycin could be clarified by the common use of macrolides in empirical treatment.

S. aureus is a pathogen with a wide range of virulence factors. The severity of $S$. aureus infections may be related to the production of some of these toxins. Exotoxins provide tissue destruction and escape from the host immune response. Toxins such as $\alpha$-hemolysin or PVL cause cytolysis of leukocytes and erythrocytes (24). PVL is a virulence marker that is often identified in CA-MRSA strains associated with necrotizing pneumonia and severe skin and soft tissue infections. The lukS-lukF genes encoding the PVL toxin are located in a phage, and can be transferred among S. aureus (25). The studies conducted in our country have revealed that PVL is spread 
at different rates between MSSA, CA-MRSA and HA-MRSA isolates without discrimination (26). All S. aureus strains were $p v l$-negative in our study. It was interpreted that these strains had been isolated from the carriers and not infectious agents.

Superantigens activate T-lymphocytes and macrophages lead to the extreme release of inflammatory cytokines, resulting in septic shock. At least 20 serologically distinct staphylococcal superantigens have been described, including SEs A through V and TSST-1. These bacterial toxins are pyrogenic and related to food poisoning and TSS. SEA and SED are the first and second most common staphylococcal toxins associated with food poisoning worldwide (27). According to these data, SEA was the most common toxin (40.1\%) in hospital- and community-acquired $S$. aureus isolates in a study from Turkey (28). In the present study, the seg gene was the most common (89.4\%). In relation to the standard enterotoxin genes, the $\sec$ gene $(52.9 \%)$ was found to be the most frequent gene, followed by sea $(13.5 \%)$. None of the $S$. aureus isolates harbored see. It was only determined in less than $1 \%$ of the samples in various studies (29-31).

Enterotoxigenic $S$. aureus strains with a combination of different SE genes can also promote the incidence and severity of $S$. aureus infections. In this study, the most common combinations detected were seg plus sei and seg plus sec in $65.4 \%$ and $49 \%$ of all isolates, respectively. Only 7 isolates encoded a single gene.

S. aureus isolates producing TSST-1 has been most commonly isolated from patients with important clinical symptoms. The tst gene encoding the TSST-1 was detected in 29 $(27.9 \%)$ isolates in our study at similar rates to another study including healthy people (32).

S. aureus strains harboring ETs can cause SSSS and impetigo. Although there are differences in the prevalence between countries, approximately $5 \%$ of $S$. aureus human isolates produce ETs $(25,29)$. However, these genes showed significantly higher rates in nasal and clinical MSSA strains in the study (30). In our study, 3 (2.9\%) strains carried the eta gene, encoding the exfoliative toxin A; however, all isolated $S$. aureus strains were negative for the exfoliative toxin $B$ gene. In a study conducted in our country, these genes were not detected in healthy controls but $e t b$ was determined in $18(58.1 \%)$ patients with psoriasis, suggesting a potential relationship (33).

In conclusion, a moderate rate of $S$. aureus carriage and very low frequency of MRSA were detected in healthy students. $S$. aureus nasal isolates showed a very high prevalence of staphylococcal enterotoxin genes and the tst gene. Most $S$. aureus isolates were susceptible to antimicrobial agents. In this study, a large number of virulence factors were examined in $S$. aureus nasal isolates, and the data obtained from this study can be used for monitoring the prevalence of virulence genes in $S$. aureus strains isolated from nasal carriers.

Ethics Committee Approval: Ethics committee approval was received for this study from the ethics committee of Selçuk University Faculty of Medicine.

Informed Consent: The students were informed about the procedure and verbal informed consents were obtained.

Peer-review: Externally peer-reviewed.

Author contributions: Concept - H.T.D., U.A.; Design - H.T.D., U.A. ; Supervision - D.F., H.T.D.; Resource - T.M., M.D.; Materials - G.D.; Data Collection \&/or Processing - G.D.; Analysis \&/or Interpretation - H.T.D., U.A., D.F.; Literature Search - H.T.D.; Writing - H.T.D., D.F.; Critical Reviews - H.T.D., U.A., D.F.

Acknowledgements: We thank to Meral Demirayak for her contributions.

Conflict of Interest: No conflict of interest was declared by the authors.

Financial Disclosure: This study was financially supported by Tales medical. The sponsor played no role in the study.

\section{REFERENCES}

1. Miller LG, Perdreau-Remington F, Rieg G, Mehdi S, Perlroth J, Bayer AS, et al. Necrotizing fasciitis caused by communityassociated methicillin-resistant Staphylococcus aureus in Los Angeles. N Engl J Med 2005;352:1445-53. [CrossRef]

2. Wertheim HF, Melles DC, Vos MC, van Leeuwen W, van Belkum A, Verbrugh HA, et al. The role of nasal carriage in Staphylococcus aureus infections. Lancet Infect Dis 2005;5:751-62. [CrossRef]

3. van Belkum A, Verkaik NJ, de Vogel CP, Boelens HA, Verveer J, Nouwen JL, et al. Reclassification of Staphylococcus aureus nasal carriage types. J Infect Dis 2009;199:1820-6. [CrossRef]

4. von Eiff C, Becker K, Machka K, Stammer H, Peters G. Nasal carriage as a source of Staphylococcus aureus bacteremia. Study Group. N Engl J Med 2001;344:11-6. [CrossRef]

5. Rebollo-Perez J, Ordonez-Tapia S, Herazo-Herazo C, ReyesRamos N. Nasal carriage of Panton Valentine leukocidin-positive methicillin-resistant Staphylococcus aureus in healthy preschool children. Rev Salud Publica (Bogota) 2011;13:82432. [CrossRef]

6. Bloomfield SF, Cookson BD, Falkiner FR, Griffith C, Cleary V. Methicillin-resistant Staphylococcus aureus, Clostridium difficile, and extended-spectrum $\beta$-lactamase-producing Escherichia coli in the community: assessing the problem and controlling the spread. Am J Infect Control 2007;35:86-8. [CrossRef]

7. Sakwinska O, Kuhn G, Balmelli C, Francioli P, Giddey M, Perreten V, et al. Genetic diversity and ecological success of 
colonizing Staphylococcus aureus. Appl Environ Microbiol 2009;75:175-83. [CrossRef]

8. Mertz D, Frei R, Periat N, Zimmerli M, Battegay M, Flückiger U, et al. Exclusive Staphylococcus aureus throat carriage: at-risk populations. Arch Intern Med 2009;169:172-8. [CrossRef]

9. Ben Slama K, Gharsa H, Klibi N, Jouini A, Lozano C, GómezSanz E, et al. Nasal carriage of Staphylococcus aureus in healthy humans with different levels of contact with animals in Tunisia: genetic lineages, methicillin resistance, and virulence factors. Eur J Clin Microbiol Infect Dis 2011;30:499-508. [CrossRef]

10. Jarraud S, Mougel C, Thioulouse J, Lina G, Meugnier H, Forey F, et al. Relationships between Staphylococcus aureus genetic background, virulence factors, agr groups (alleles), and human disease. Infect Immun 2002;70:631-41. [CrossRef]

11. Nhan TX, Leclercq R, Cattoir V. Prevalence of toxin genes in consecutive clinical isolates of Staphylococcus aureus and clinical impact. Eur J Clin Microbiol Infect Dis 2011;30:719-25. [CrossRef]

12. Xu SX, McCormick JK. Staphylococcal superantigens in colonization and disease. Front Cell Infect Microbiol 2012;2:52. [CrossRef]

13. Clinical and Laboratory Standards Institute (CLSI). 2011. Performance standards for antimicrobial susceptibility testing. Twenty-first informational supplement, M100-S21, National Committee for Clinical Laboratory Standards, Wayne PA.

14. Oliveira DC, De Lencastre H. Multiplex PCR strategy for rapid identification of structural types and variants of the mec element in methicillin-resistant Staphylococcus aureus. Antimicrob Agents Chemother 2002;46:2155-61. [CrossRef]

15. Kim CH, Khan M, Morin DE, Hurley WL, Tripathy DN, Kehrli Jr M, et al. Optimization of the PCR for detection of Staphylococcus aureus nuc gene in bovine milk. J Dairy Sci 2001;84:7483. [CrossRef]

16. Lina G, Piemont Y, Godail-Gamot F, Bes M, Peter MO, Gauduchon $\mathrm{V}$, et al. Involvement of Panton-Valentine leukocidinproducing Staphylococcus aureus in primary skin infections and pneumonia. Clin Infect Dis 1999;29:1128-32. [CrossRef]

17. Monday SR, Bohach, GA. Use of multiplex PCR to detect classical and newly described pyrogenic toxin genes in staphylococcal isolates. J Clin Microbiol 1999;37:3411-4.

18. Sila J, Sauer P, Kolar M. Comparison of the prevalence of genes coding for enterotoxins, exfoliatins, Panton-Valentine leukocidin and tsst- 1 between methicillin-resistant and methicillin-susceptible isolates of Staphylococcus aureus at the university hospital in Olomouc. Biomed Pap Med Fac Univ Palacky Olomouc Czech Repub 2009;153:215-8. [CrossRef]

19. Manious AG, Hueston WJ, Everett CJ, Diaz VA. Nasal carriage of Staphylococcus aureus and methicillin-resistant $\mathrm{S}$. aureus in the United States, 2001-2002. Ann Fam Med 2006;4:132-7. [CrossRef]

20. Zanelli G, Sansoni A, Zanchi A, Cresti S, Pollini S, Rossolini GM, et al. Staphylococcus aureus nasal carriage in the community: A survey from central Italy. Epidemiol Infect 2002;129:417-20. [CrossRef]

21. Kiliç A, Mert G, Senses Z, Bedir O, Aydogan H, Basustaoglu AC, Appelbaum PC. Molecular characterization of methicil- lin resistant Staphylococcus aureus nasal isolates from Turkey. Antonie Van Leeuwenhoek 2008;94:615-9. [CrossRef]

22. Adhikari RP, Ajao AO, Aman MJ, Karauzum H, Sarwar J, Lydecker AD, et al. Lower antibody levels to Staphylococcus aureus exotoxins are associated with sepsis in hospitalized adults with invasive S. aureus infections. $J$ Infect Dis 2012;206:915-23. [CrossRef]

23. Dinic M, Vukovic S, Kocic B, Stankovic Dordevic D, Bogdanovic M. Nasal carriage of Staphylococcus aureus in healthy adults and in school children. Acta Fac Med Naiss 2013;30:31-6.

24. DeLeo FR, Diep BA, Otto M. Host defense and pathogenesis in Staphylococcus aureus infections. Infect Dis Clin North Am 2009;23:17-34. [CrossRef]

25. Lozano C, Gomez-Sanz E, Benito D, Aspiroz C, Zarazaga M, Torres C. Staphylococcus aureus nasal carriage, virulence traits, antibiotic resistance mechanisms, and genetic lineages in healthy humans in Spain, with detection of CC398 and CC97 strains. Int J Med Microbiol 2011;301:500-5. [CrossRef]

26. Duman Y, Tekeroğlu MS, Otlu B. Investigation of the Presence of Panton-Valentine Leukocidin and Clonal Relationship of Community- and Hospital-Acquired Clinical Isolates of Staphylococcus aureus. Mikrobiyol Bul 2013;47:389-400. [CrossRef]

27. Pinchuk IV, Beswick EJ, Reyes VE. Staphylococcal enterotoxins. Toxins (Basel) 2010;2:2177-97. [CrossRef]

28. Yılmaz S, Kılıç A, Karagöz A, Bedir O, Uskudar Guclu A, Başustaoglu AC. Investigation of various virulence factors among the hospital and community-acquired Staphylococcus aureus isolates by real-time PCR method. Mikrobiyol Bul 2012;46:532-45.

29. Becker K, Friedrich AW, Lubritz G, Weilert M, Peters G, Von Eiff C. Prevalence of genes encoding pyrogenic toxin superantigens and exfoliative toxins among strains of Staphylococcus aureus isolated from blood and nasal specimens. J Clin Microbiol 2003;41:1434-9. [CrossRef]

30. Shukla SK, Karow ME, Brady JM, Stemper ME, Kislow J, Moore N, et al. Virulence genes and genotypic associations in nasal carriage, community-associated methicillin susceptible and methicillin-resistant USA400 Staphylococcus aureus isolates. J Clin Microbiol 2010;48:3582-92. [CrossRef]

31. Schaumburg F, Ateba Ngoa U, Kösters K, Köck R, Adegnika AA, Kremsner PG. Virulence factors and genotypes of Staphylococcus aureus from infection and carriage in Gabon. Clin Microbiol Infect 2011;17:1507-13. [CrossRef]

32. Megevand C, Gervaix A, Heininger U, Berger C, Aebi C, Vaudaux B, et al. Molecular epidemiology of the nasal colonization by methicillin-susceptible Staphylococcus aureus in Swiss children. Clin Microbiol Infect 2010;16:1414-20. [CrossRef]

33. Balci DD, Duran N, Ozer B, Gunesacar R, Onlen Y, Yenin JZ. High prevalence of Staphylococcus aureus cultivation and superantigen production in patients with psoriasis. Eur J Dermatol 2009; 19:238-42. 